\title{
Is Recycling Always the Best Option? Environmental Assessment of Recycling of Seashell as Aggregates in Noise Barriers
}

\author{
Begoña Peceño ${ }^{1}\left[\right.$, Carlos Leiva ${ }^{2}$, Bernabé Alonso-Fariñas ${ }^{2, *} * \mathbb{D}$ and \\ Alejandro Gallego-Schmid ${ }^{3, *}$ \\ 1 Facultad de Ciencias del Mar, Escuela de Prevención de Riesgos y Medioambiente, \\ Universidad Católica del Norte, Larrondo 1281, Coquimbo 1780000, Chile; begopc@ucn.cl \\ 2 Departamento de Ingeniería Química y Ambiental, Escuela Técnica Superior de Ingeniería, \\ Universidad de Sevilla, Camino de los Descubrimientos s/n, 41092 Seville, Spain; cleiva@us.es \\ 3 Tyndall Centre for Climate Change, School of Mechanical, Aerospace and Civil Engineering, \\ The University of Manchester, Pariser Building, Sackville Street, Manchester M13 9PL, UK \\ * Correspondence: bernabeaf@us.es (B.A.-F.); alejandro.gallegoschmid@manchester.ac.uk (A.G.-S.)
}

Received: 5 June 2020; Accepted: 28 June 2020; Published: 2 July 2020

\begin{abstract}
Waste recycling is an essential part of waste management. The concrete industry allows the use of large quantities of waste as a substitute for a conventional raw material without sacrificing the technical properties of the product. From a circular economy point of view, this is an excellent opportunity for waste recycling. Nevertheless, in some cases, the recycling process can be undesirable because it does not involve a net saving in resource consumption or other environmental impacts when compared to the conventional production process. In this study, the environmental performance of conventional absorption porous barriers, composed of $86 \mathrm{wt} \%$ of natural aggregates and $14 \mathrm{wt} \%$ cement, was compared with barriers composed of $80 \mathrm{wt} \%$ seashell waste and $20 \mathrm{wt} \%$ cement through an attributional cradle-to-grave life cycle assessment. The results show that, for the 11 environmental impact categories considered, the substitution of the natural aggregates with seashell waste involves higher environmental impacts, between $32 \%$ and $267 \%$. These results are justified by the high contribution to these impacts of the seashell waste pre-treatment and the higher cement consumption. Therefore, the recycling of seashells in noise barrier manufacturing is not justified from an environmental standpoint with the current conditions. In this sense, it could be concluded that life cycle assessments should be carried out simultaneously with the technical development of the recycling process to ensure a sustainable solution.
\end{abstract}

Keywords: life cycle assessment; circular economy; environmental sustainability; mollusk shell; porous concrete; construction

\section{Introduction}

The construction industry is one of the most important sectors for economic development in the European Union [1]. The sector demands high amounts of natural resources and energy, consuming around $40 \%$ of the global energy demand [2,3]. In light of this fact, many potential solutions have been studied, highlighting among them the use of waste instead of natural resources. The concrete industry, for instance, allows the use of large quantities of waste as a substitute for a conventional raw material, without sacrificing the technical properties of the product [4,5]. From a circular economy point of view, the benefit of this proposal is two-fold: The decrease of natural resource consumption $[6,7]$, and the reduction of air, soil, and groundwater pollution associated with landfilling [8], which can negatively affect human health, environment, and biota $[9,10]$. However, the recycling process could 
be undesirable from an environmental perspective if there is no real saving in energy, raw materials, and water consumption, or in pollutant emissions [11].

Natural aggregates, one of the primary ingredients in concrete, can be obtained from: (1) Naturally occurring unconsolidated sand and gravel; and (2) quarries, by crushing bedrock to obtain crushed stone and sand [12]. The first alternative can cause irreparable damage to the river ecosystems, such as channel degradation and the incision of the entire fluvial system [13]. For this reason, in countries, such as Spain, the extraction of aggregates from gravel pits is restricted by environmental laws to protect the biodiversity and biological resources of rivers [14]. Currently, natural aggregates are mainly obtained from quarries [15]. In 2015, 2660 million tons of aggregates were produced in Europe from quarries, and $47 \%$ were crushed gravel, gravel, and sand [16].

On the one hand, an increasing amount of different types of waste is being recycled as fine and coarse aggregates in concrete manufacturing as a substitution for natural aggregates. Some examples are ashes, bottom ashes, and slags [17]; construction and demolition wastes [18]; and farming wastes, such as corn, wheat, bamboo, coconut shells, and olive stone $[19,20]$. On the other hand, the aquaculture industry produces between $6,000,000$ and $8,000,000$ tons of waste worldwide annually and only $25 \%$ is recycled [21], and the rest is usually dumped in coastal waters or landfills [22]. Part of the seashell waste generated by the aquaculture industry is recycled as lime substitute, wastewater decontaminant, soil conditioner, fertilizer constituent, feed additive, and liming agent [23]. However, these recycling options are not able to consume a significant amount of seashell waste produced annually [24].

Several authors have proposed the recycling of seashell waste as an aggregate in mortars, substituting natural aggregates totally replacing limestone aggregates from quarry [25] and employing it alone [26,27] or with other waste, such as fly ash [28], for silica sand substitution. Due to the large amount of organic matter and chloride present in the waste [29], and to comply with the requirements of construction material standards [30], seashell waste pre-treatment, consisting of washing and calcination, is required, regardless of the specific application: Insulation construction materials [31], both conventional [32] and marine concretes [33]; cement mortars for masonry and plastering [34]; and cement-based bricks [35]. This pre-treatment involves the use of significant amounts of resources and energy. However, the specific quantification of the potential environmental benefits of the recycling of seashell waste for natural aggregate substitution is still lacking in the literature. Only two environmental impact assessments were reported in the literature, with opposite conclusions in favor of and against seashell waste recycling as a source of $\mathrm{CaCO}_{3}[36,37]$.

The World Health Organization (WHO) recommends reducing noise levels produced by road traffic below 53 decibels $(\mathrm{dB})$ as road traffic noise above this level is associated with adverse health effects [38]. The high level of noise pollution led the European Union to develop a specific directive to manage environmental noise [39]. The growing number of these types of policies has led to an increase in the production of noise barriers [40]. Related to this, the design of noise barriers with porous concrete (PC) as a mitigation measure has started to be incorporated into new road construction projects [40]. The present study is part of a research project where different alternatives for seashell recycling in construction materials are technically and environmentally assessed. Noise barriers were chosen within the scope of this research project because local industries could consume the full amount of waste annually produced. In a recently published work, concrete-based noise barriers with recycled seashell waste were obtained with similar technical properties to barriers made with natural aggregates [41].

This study aimed to analyze the environmental impacts of the use of seashell as an aggregate in porous concrete for noise barriers through life cycle assessment (LCA) for the first time, and to identify the potential advantages of this proposed recycling process. The use of LCA makes it possible to determine whether this recycling alternative is a good option for seashell waste management in terms of environmental sustainability. The study focused on the mussel-canning industries from Galicia (NW Spain), which produce 267,000 tons of mussels annually [42] and around 150,000 tons of seashell waste [43]. 


\section{Materials and Methods}

This LCA was conducted according to the guidelines in ISO 14040/44 [44,45]. The data and main assumptions considered are detailed in the following sections.

\subsection{Goal and Scope}

The main goal of this study was to assess the life cycle environmental sustainability of a new noise barrier manufactured from porous concrete produced with seashell waste (PCSW), and compare it with a conventional noise barrier made of concrete produced with natural aggregates from quarry (PCNA).

The scope of the study was from 'cradle to grave' and the main stages for PCSW and PCNA systems are the following (Figure 1):

- $\quad$ Extraction and treatment of raw materials:

- Cement.

- Natural aggregates (sand, gravel and crushed gravel) for PCNA.

- Seashell waste for PCSW, which needs a pre-treatment consisting of storing, washing, calcination, and milling to obtain fine and coarse aggregates.

- Production of the noise barrier:

- Mixing and kneading: Cement and aggregates or seashell waste are mixed with water.

- Molding: Concrete is molded (see Figure S1 in Supplementary Materials (SI)).

- Cured: Hardening process.

- Dismantling: Removal from the mold where the mixture is supported.

- Use. This stage is considered to have a negligible impact in the comparison according to different suppliers of acoustic barriers [46,47].

- End-of-life. Landfilling of the waste from the extraction and treatment of raw materials, the production process, and the end-of-life of the noise barrier.

- Transport. It includes the transport of the seashell waste to the pre-treatment facility, of the raw materials to the noise barrier factory, of the porous concrete panel to the location of use, and of the waste to the landfill.

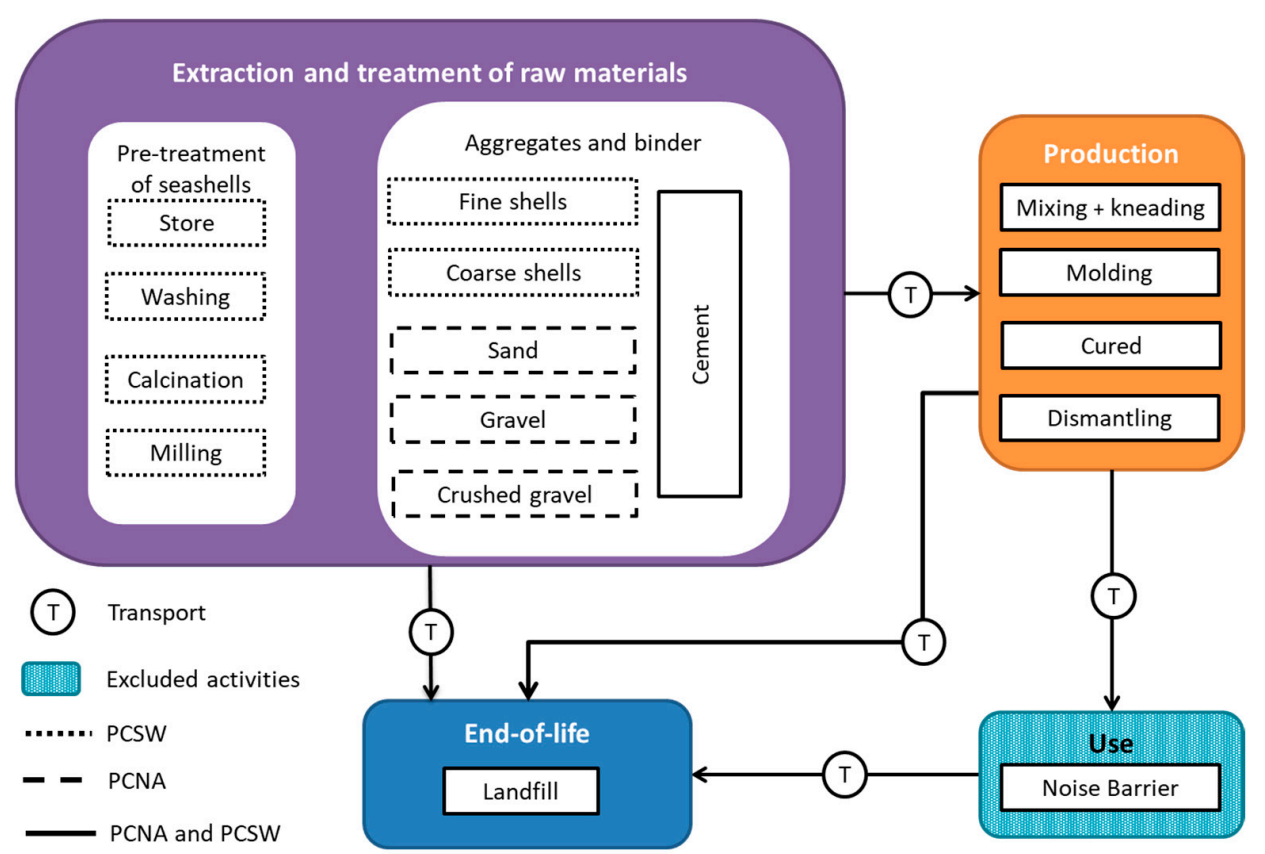

Figure 1. System boundaries for the life cycle of noise barriers using porous concrete with natural aggregates (PCNA) and aggregates from seashell waste (PCSW). 
The defined functional unit (FU) is the production of $1 \mathrm{~m}^{2}$ of noise barrier. This FU was selected to compare the environmental impact of both products for the same area of sound absorption and mechanical properties. As can be seen in our previous work [41], both types of panels (PCNA and PCSW) can be classified as the A2 category of the acoustic absorption assessment index, according to EN 1793-1 [48], for the same thickness. In addition, the mechanical and durability tests showed similar results for both materials [41].

\subsection{Life Cycle Inventory}

Table 1 shows the inventory data for both types of noise barriers, with natural aggregates (PCNA) and seashell waste (PCSW). Inventory data for the seashell waste pre-treatment were adapted from Iribarren et al. [37]. Consumptions for PCSW production were obtained from Peceño et al. [41]. The raw material and energy consumption of PCNA were determined from the manufacturers' data. The background data were sourced from the Ecoinvent v3.1 database [49].

Table 1. Life cycle inventory data for $1 \mathrm{~m}^{2}$ of noise barrier using porous concrete from natural aggregates (PCNA) and seashell waste (PCSW).

\begin{tabular}{|c|c|c|}
\hline Parameters & PCNA & PCSW \\
\hline \multicolumn{3}{|c|}{ Extraction and treatment of raw materials } \\
\hline \multicolumn{3}{|c|}{ Pre-treatment of seashells 1} \\
\hline Seashell waste $(\mathrm{kg})$ & - & 301.8 \\
\hline Propane $(\mathrm{kg})$ & - & 6.3 \\
\hline Diesel (g) & - & 140.0 \\
\hline Aluminum sulphate $(\mathrm{g})$ & - & 7.2 \\
\hline Chlorine dioxide $(\mathrm{g})$ & - & 1.8 \\
\hline Water $(\mathrm{kg})$ & & 280.0 \\
\hline Electricity, low voltage (kWh) & - & 29.4 \\
\hline \multicolumn{3}{|c|}{ Aggregates and cement } \\
\hline Gravel (kg) & 48.0 & - \\
\hline Sand $(\mathrm{kg})$ & 96.0 & - \\
\hline Crushed gravel $(\mathrm{kg})$ & 69.1 & \\
\hline Fine shells (kg) & - & 90.4 \\
\hline Coarse shells (kg) & - & 90.4 \\
\hline Cement $(\mathrm{kg})$ & 35.2 & 45.2 \\
\hline \multicolumn{3}{|c|}{ Production } \\
\hline Water $(\mathrm{kg})$ & 14.6 & 27.1 \\
\hline Electricity (low voltage) (kWh) & 0.5 & 0.4 \\
\hline \multicolumn{3}{|c|}{ End-of-life } \\
\hline $\begin{array}{l}\text { Landfill (including waste from raw material } \\
\text { treatment, production and end-of-life) (kg) }\end{array}$ & 262 & 240 \\
\hline \multicolumn{3}{|c|}{ Transport } \\
\hline Seashell waste to pre-treatment facility (tkm) & - & 3.02 \\
\hline Raw materials to the factory $(\mathrm{tkm})$ & 11.2 & 18.5 \\
\hline From factory to use place (tkm) & 52.4 & 48.6 \\
\hline From use place to landfill (tkm) & 1.0 & 0.9 \\
\hline
\end{tabular}

${ }^{1}$ Only the main consumptions for the pre-treatment of seashell are included here. A detailed inventory table for this process, adapted from [37], is given in Supplementary Materials (Table S1).

\subsubsection{Raw Materials}

As mentioned above, previously used as aggregates, seashell waste from the canning industry must be pre-treated to satisfy the requirements of the EN 1744-1 standard [30] regarding the maximum quantity of organic matter and chloride [29]. The first step was the washing of the seashell waste. Wash water was treated subsequently with chlorine dioxide in a ratio of $6 \mathrm{mg}$ per $\mathrm{kg}$ seashell waste. To remove suspended solids from the wash water, aluminum sulphate was added as a coagulant at a 
ratio of $24 \mathrm{mg}$ per $\mathrm{kg}$ seashell waste. Afterwards, to remove the organic matter left, the seashell waste was calcined at $550{ }^{\circ} \mathrm{C}$ for $15 \mathrm{~min}$. The calcination temperature was limited to $550{ }^{\circ} \mathrm{C}$ to avoid the decomposition of $\mathrm{CaCO}_{3}$ (90 wt \% of the seashell) to $\mathrm{CaO}$ and $\mathrm{CO}_{2}$. Finally, the washed and calcined seashell waste were milled to obtain two different kinds of aggregates, fine and coarse, with particle sizes lower and higher than $2 \mathrm{~mm}$, respectively [37].

\subsubsection{Production}

Aggregates, cement and water were mixed and kneaded mechanically to produce the concrete mass. Afterwards, the concrete is poured into a mold of the required dimensions (see Figure S1 in Supplementary Materials). The electricity consumption reported for PCNA for these processes was also considered for PCWS but proportionally adapted to the consumed mass of each component.

For each panel, two masses were prepared: The porous concrete mass, made with fine aggregates, and the structural concrete mass, produced with coarse aggregates. Firstly, the porous concrete mass was poured into the mold. Then, a steel frame was placed, and the structural concrete was poured. The steel reinforcement was not included in the inventory since it was equal for both the PCNA and PCSW. The next step was the curing, which is the hardening process of the panels and where water evaporation is produced. The curing process was considered finished after 28 days, when the mold was dismantled.

For PCNA, while gravel and sand were used for a layer of structural concrete, crushed gravel was used for a layer of porous concrete. The structural concrete mass was composed of $57 \mathrm{wt} \%$ sand, $29 \mathrm{wt} \%$ gravel, and $14 \mathrm{wt} \%$ cement. The amount of water added was $46 \mathrm{wt} \%$ with respect to the amount of cement. The porous concrete mass was composed of $86 \% \mathrm{wt}$ of crushed gravel and $14 \mathrm{wt} \%$ cement. Then, $30 \mathrm{wt} \%$ water was added with respect to the amount of cement. The mass of the noise panel was $262 \mathrm{~kg} / \mathrm{m}^{2}$ per functional unit.

In the case of PCSW, a mass ratio of 80:20 seashell waste: cement was added for both layers of concrete, porous (with coarse shells) and structural (with fine shells). The amount of water added was $60 \%$ wt with respect to the amount of cement, to ensure the workability of the mass [41]. The total mass of the noise panel was $240 \mathrm{~kg} / \mathrm{m}^{2}$ per functional unit.

\subsubsection{End-of-Life}

After their use, both PCNA and PCSW panels are considered as construction and demolition waste (CDW), according to section 17 of the European Waste Catalogue [50]. Following the most recent data for CDW treatment in Spain, 100\% of the waste was assumed to be sent to the landfill [51].

\subsubsection{Transport}

For both types of alternatives, the production of the concrete was assumed to be in the concrete plant of General de Hormigones in Meis (Galicia, NW Spain). This company commercializes different concrete-made products with natural aggregates, including porous concrete. Both the closest gravel extraction quarry and cement factory of General de Hormigones were chosen for the study: Gravel extraction in Salcedo (22 km from Meis) and cement industry in Ouras (186 km from Meis). According to Barros et al. [52], seashell waste is pre-treated in Caliza Marina Company, located in Boiro (39 km from Meis), while mussel-canning industries are located in Rianxo [52] (10 km from Boiro). Distances were measured using the Google MapsTM distance measurement tool [53]. Once it was produced, the noise barrier of porous concrete was assumed to travel a distance of $200 \mathrm{~km}$ to the final installation on a road. Regarding the end-of-life, generated waste was considered to be transported a distance of $15 \mathrm{~km}$ to the landfill [54]. All transport was done by road, and a 16-32-tonne Euro 6 truck was considered, according to the classification included in Regulation (EC) No 715 (2007) [55].

\subsection{Sensitivity Analysis}

To reduce the necessary heat consumption for seashell waste calcination during its pre-treatment, other authors have proposed lower temperatures than $550{ }^{\circ} \mathrm{C}$, reported by Barros et al. [56]. On the 
one hand, Neves and Manos [57] and Sahari and Aniza Mijan [58] calcined seashell waste at $250{ }^{\circ} \mathrm{C}$. On the other hand, Martinez-Garcia et al. [59] calcined seashell waste at $135^{\circ} \mathrm{C}$. Due to the expected significant influence that heat production for calcination could have on the results of the environmental assessment, the present work also studied the environmental impact of PCSW for the two other calcination temperatures aside from $550{ }^{\circ} \mathrm{C}$ through a sensitivity analysis: $135{ }^{\circ} \mathrm{C}$ (PCSW-135) and $250{ }^{\circ} \mathrm{C}$ (PCSW-250). Life cycle inventories of PCSW-135 and PCSW-250 are provided in Table S1 in Supplementary Materials.

\subsection{Environmental Impact Assessment}

The LCA software SimaPro version 8.0.4 9 (PRé Consultants, B.V.: Amersfoort, The Netherlands, 2016) [60] was used for life cycle modelling, and the CML-IA (version 3.03) mid-point impact assessment method [61] was applied to calculate the environmental impacts. The following impacts were considered: Abiotic depletion potential of elements (ADPe), abiotic depletion potential of fossil resources (ADPf), acidification potential (AP), eutrophication potential (EP), global warming potential (GWP), human toxicity potential (HTP), marine aquatic ecotoxicity potential (MAETP), freshwater aquatic ecotoxicity potential (FAETP), ozone depletion potential (ODP), photochemical oxidant creation potential (POCP), and terrestrial ecotoxicity potential (TETP).

\section{Results and Discussion}

\subsection{Comparison of PCNA and PCSW}

As illustrated in Figure 2, PCNA has the lowest values in all impact categories considered in this study, despite the recycling of the seashell waste in the PCSW material. Overall, the impacts associated with PCSW are between 32\% (TETP) and 267\% (ODP) higher in comparison to PCNA.

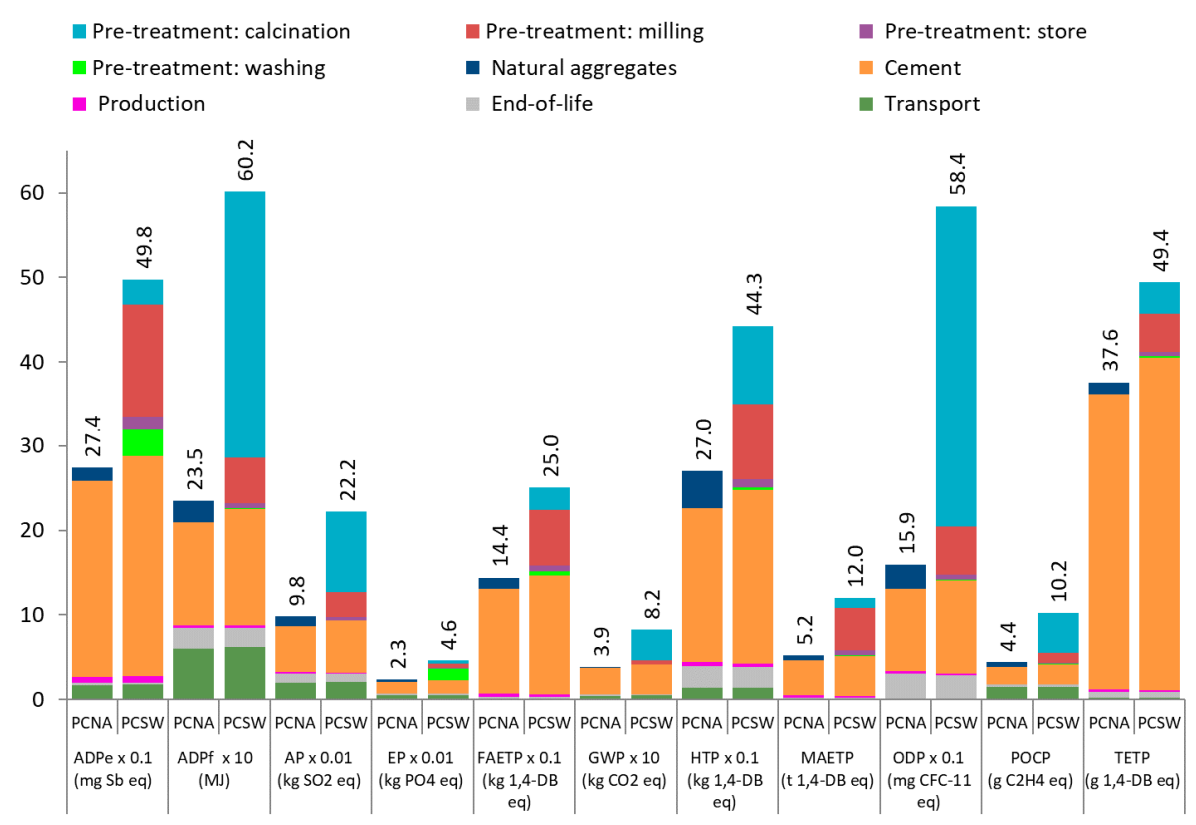

Figure 2. Life cycle environmental impacts of PCNA and PCSW noise barriers. Some impacts should be multiplied by the factor shown to obtain the original values. ADPe: abiotic depletion potential of elements, ADPf: abiotic depletion potential of fossil resources, AP: acidification potential, EP: eutrophication potential, FAETP: freshwater aquatic ecotoxicity potential, GWP: global warming potential, HTP: human toxicity potential, MAETP: marine aquatic ecotoxicity potential, ODP: ozone layer depletion potential, POCP: photochemical oxidants creation potential, TETP: terrestrial ecotoxicity potential, PCNA: porous concrete with natural aggregates and PCSW: porous concrete with seashell waste calcined at $550{ }^{\circ} \mathrm{C}$. 
The seashell waste pre-treatment is the main contributor to seven impact categories in the case of PCSW barriers: ODP (76\%), ADPf (63\%), POCP (59\%), AP (58\%), MAETP (57\%), EP (51\%), and GWP $(50 \%)$. The ADPf impact is mainly associated with the consumption of fossil fuels during calcination. In the case of the ODP, fossil fuel transportation produces emissions of bromotrifluoride and halon 1301 that contribute to this impact. For AP, the impact is mostly caused by the $\mathrm{SO}_{\mathrm{x}}, \mathrm{NO}_{\mathrm{x}}$, and $\mathrm{NH}_{3}$, emissions generated from the burning of propane to produce the heat used for calcination The $\mathrm{SO}_{2}$, $\mathrm{CO}, \mathrm{C}_{4} \mathrm{H}_{10}$, and $\mathrm{CH}_{4}$ emissions also released in the combustion of propane generate a significant contribution to the POCP impact. The same cause, the propane combustion, contributed significantly to the GWP impact due to the emissions of $\mathrm{CO}_{2}, \mathrm{CH}_{4}$, and $\mathrm{N}_{2} \mathrm{O}$. In the case of EP, the impact is mainly associated with the aquatic emissions of $\mathrm{PO}_{4}{ }^{3-}, \mathrm{NO}, \mathrm{COD}$, and $\mathrm{NO}_{2}$ released in the washing process of seashell waste. Finally, for MAETP, the impact is mainly caused by the $\mathrm{HF}, \mathrm{Be}, \mathrm{Ni}$, and $\mathrm{Ba}$ emissions during the mining of the coal burned for the generation of electricity necessary for the milling. The pretreatment of the shells is the second most important contributor to the other four impact categories: ADPe $(42 \%)$, FAETP $(41 \%)$, HTP (44\%), and TETP (18\%). Most of these impacts are associated with the electric consumption in the milling process and, more specifically, from the extraction of coal used for electricity generation. The consumption of electricity in the milling of fine shells used in the structural layer of concrete is three times higher than in the milling of the coarse shells for the porous concrete layer.

In the case of PCNA, the extraction of natural aggregates only contributes significantly to ODP $(18 \%)$ due to the emissions associated with the consumption of diesel used in heavy machinery in the quarry. The impacts associated with natural aggregates are much lower than those associated with recycled seashells. The pre-treatment of the seashell waste generates between 4 (HTP) and 22 (GWP) times higher impacts compared to the natural aggregates' production.

Cement production is the most significant contributor in all categories (47-93\%) for PCNA and, for PCSW, in those four impacts in which the pre-treatment does not entail most of the burdens (HTP $(46 \%)$, ADPe (52\%), FAEP $(56 \%)$, and TETP $(80 \%))$. Cement contributes significantly to the impacts of TETP $(>80 \%)$, FAETP $(>56 \%)$, ADPe $(>52 \%)$, and HTP $(>46 \%)$ for both types of barriers. The impacts per FU due to the cement consumption are higher in the case of PCSW because more cement is needed to produce the noise barrier $(35.20 \mathrm{~kg} / \mathrm{FU}$ in the case of PCNA versus $45.20 \mathrm{~kg} / \mathrm{FU}$ in the case of PCSW as illustrated in Table 1). The higher consumption of cement in PCSW is necessary to accomplish the required mechanical properties due to the shape and porosity of shell wastes [41,62]. The TETP and HTP impacts are associated with the emissions of heavy metals, such as chromium, zinc, tin, and lead, and dioxins in the production of clinker. The impacts of FAETP and ADPe are mainly caused by the mining and extraction of fossil fuels used in the generation of heat and electricity consumed in the cement production process.

The contribution of the production stage to the impacts is relatively low ( $<5 \%$ for PCNA and $<2 \%$ for PCSW). In this stage, there is a reduction in all the impacts of PCSW compared to PCNA except for the ADPe. The higher value for ADPe is caused by the higher demand for water consumption in PCSW production (27.10 kg/FU for PCSW compared to $14.60 \mathrm{~kg} / \mathrm{FU}$, see Table 1). The lower impacts in the rest of the categories are caused by a slightly lower consumption of electricity in the case of PCSW $\left(0.43 \mathrm{kWh} / \mathrm{FU}\right.$ for PCSW compared to $0.47 \mathrm{kWh} / \mathrm{FU}$ for PCNA). There is a mass difference per $1 \mathrm{~m}^{2}$ ( $240 \mathrm{~kg} / \mathrm{FU}$ for PCSW versus $262 \mathrm{~kg} / \mathrm{FU}$ for PCNA), and therefore, the electrical consumption for molding and kneading is lower for PCSW panels.

The end-of-life stage does not contribute significantly to the impacts $(<19 \%$ for PCNA and $<5 \%$ for PCSW). The impacts of landfilling are mainly generated by the consumption of diesel in the use of heavy machinery needed in the disposal. The difference in weight between both barriers $(262 \mathrm{~kg} / \mathrm{FU}$ for PCNA versus $240 \mathrm{~kg} / \mathrm{FU}$ for PCSW) makes the diesel consumption lower in the case of PCSW.

The transport only contributes significantly for POCP (33\% for PCNA and $15 \%$ for PCSW) and $\operatorname{ADPf}\left(25 \%\right.$ for PCNA and $10 \%$ for PCSW) due to the emissions of volatile organic compounds and $\mathrm{NO}_{\mathrm{x}}$ 
from fuel combustion. Although the global distances considered for PCSW are slightly lower than for PCRG (450 km vs. $467 \mathrm{~km}$ ), the higher amount of consumed cement increases the impacts for PCSW.

To summaries, the results show that the manufacture of the PCSW noise barrier has no environmental advantages over the PCNA noise barrier due to the high environmental burden of the pre-treatment of the seashells, the increase in the consumption of cement, and the low environmental load of the natural aggregates. Therefore, to apply wastes instead of natural aggregates for the production of porous concrete, it is necessary to look for sources of waste that require more sustainable pre-treatment and do not involve an increase in cement consumption.

As far as we are aware, there are no other comprehensive LCA studies of the use of recycled seashells for noise barriers, so a direct comparison with the literature is not possible. The most similar studies are from Iribarren et al. [37] and Alvarenga et al. [36], which analyzed the life cycle of seashell waste management, considering the recycling of seashells as $\mathrm{CaCO}_{3}$ versus landfilling. The comparison of the results should only be considered as illustrative due to the difference in the raw materials (e.g., different types of seashells and final products), processes, and LCA parameters (e.g., system boundaries, FU, or impact categories) considered. The LCA results reported by Iribarren et al. [37] showed that the recycling of seashells as $\mathrm{CaCO}_{3}$ presents disadvantages compared with landfilling. Still, the authors noted that, despite these results from the LCA analysis, social concerns could be an argument against landfilling [37]. However, in the case of Alvarenga et al. [36], the recycling of seashell waste as $\mathrm{CaCO}_{3}$ generated lower environmental impacts than landfilling in all the impacts (between $1 \%$ and $85 \%$ ). These results are justified because only energy and water consumption required for the pre-treatment of shells were considered, thus reducing the environmental burdens. In addition, the recycled seashell is credited with the avoided environmental impacts of the production of $\mathrm{CaCO}_{3}$ [36].

\subsection{Sensitivity Analysis}

As shown in Figure 3, the reduction in the calcination temperature involves a reduction in the environmental impacts for all categories under study. The percentage of reduction versus the base case (PCSW), with a calcination temperature of $550{ }^{\circ} \mathrm{C}$, depends on the impact category and ranges from $3 \%$ (PCSW-250)-5\% (PSW-135) for ADPe to 36\% (PCSW-250)-52\% (PSW-135) for ODP. These differences are justified by the different percentages of contribution of the calcination process to the environmental burdens of each impact category.

The lowest reductions in the impacts $(<10 \%$ for PCSW-135 and PCSW-250) are for TETP, FAETP, ADPe, and MAETP. As shown in Section 3.1, these impacts are mainly associated with the production of cement and the electricity consumption of the milling process but not with the calcination process. Despite this, and if only the pre-treatments are compared, there is a reduction in the four impact categories mentioned by $8-23 \%$ for PCSW-250 and by $11-33 \%$ for PCSW-135, compared to PCSW.

Moderate reductions are observed for EP and HTP when the heating temperature is reduced. In the case of the EP, the impact is reduced between 18\% (PCSW-250) and 26\% (PCSW-135) compared with PCSW. The reduction is between 11\% (PCSW-250) and 16\% (PCSW-135) for HTP. The minimization of propane consumption decreases aerial $\mathrm{NO}_{\mathrm{x}}$ emissions and, therefore, the EP impact. This reduction of consumption also decreases the $\mathrm{PO}_{4}{ }^{3-}, \mathrm{NO}_{3}{ }^{-}, \mathrm{Se}$, and $\mathrm{Ni}$ emissions in the extracting, processing and the use of propane and, therefore, causes a reduction in the HTP impact.

Finally, the ADPf, AP, POCP, GWP, and ODP impacts have the most significant decreases ( $>22 \%$ for PCSW-250 and $>32 \%$ for PCSW-135). These reductions are justified by the decline in the consumption of propane between 60\% (PCSW-250) and 78\% (PCSW-135), which is the main contributor to these impacts (see Section 3.1). If only the pre-treatment is compared, the decreases in these impacts are $>38 \%$ for PCSW- 250 and $>56 \%$ for PCSW- 135 compared to PCSW. 


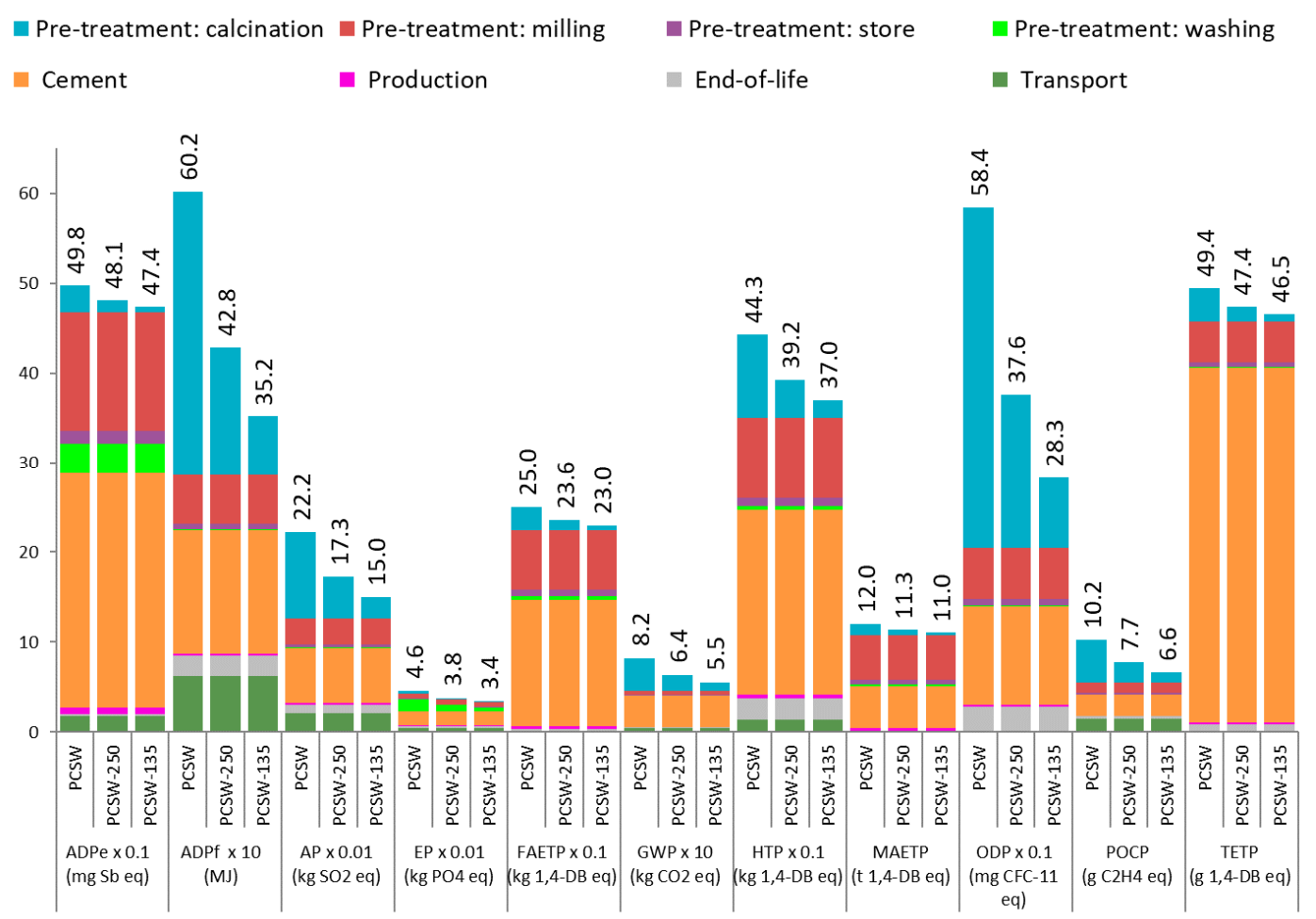

Figure 3. Environmental influence of different calcination temperatures in the pre-treatment of seashell waste. Some impacts should be multiplied by the factor shown to obtain the original values. PCSW-250: porous concrete with seashell waste heated at $250{ }^{\circ} \mathrm{C}, \mathrm{PCSW}-135$ : porous concrete with seashell waste heated at $135^{\circ} \mathrm{C}$. For the rest of the nomenclatures, consult Figure 2.

The results for PCNA and the best heating temperature alternative, PCSW-135, are compared in Figure 4. The reduction of the calcination temperature to $135{ }^{\circ} \mathrm{C}$ is not enough to allow the recycling seashells to be a better alternative compared with the use of natural aggregates for any impact category. TETP shows the closest impact between PCSW-135 and PCNA, with a 24\% difference. ODP (28.3 mg CFC-11 for PCSW-135 compared to $15.9 \mathrm{mg}$ CFC-11 for PCNA) and MAETP (11.0 t 1.4 DB eq. for PCSW-135 and 5.2 t 1.4 DB eq. for PCNA) have the most significant differences with respect to PCNA, $78 \%$ and $113 \%$, respectively. These differences are mainly caused by the higher consumption of fossil fuels for cement production and the demand for fossil fuels in the pre-treatment of the seashell waste. Due to the reduction in the calcination temperature, the contribution of propane consumption to MAETP is only $24 \%$ compared with the total contribution of the complete pre-treatment. However, the pre-treated shells still have 10 times more MAETP impact if compared to the natural aggregates (5.94 $\mathrm{t} \mathrm{DB}$ eq. versus $0.56 \mathrm{t} \mathrm{DB}$ eq.), mainly due to the electric consumption of the milling.

The results show that even with the lower calcination temperature $\left(135^{\circ} \mathrm{C}\right)$, the use of natural aggregates is the best alternative from an environmental standpoint. These results initially go against some of the principles of the circular economy, like preserving and enhancing natural capital [63] by controlling finite stocks [64] and designing out waste [65]. Circular economy principles have been considered by new European Union policies that promote waste prevention, recycling, and ecodesign to reduce the environmental impact [66]. Several tools have been developed for circular economy principle implementation [67], and they have been used by researchers in order to attain more eco-friendly designs and processes [68]. However, in some cases, as shown in the present study, the recycling of waste can imply an increase in the environmental impacts, due to higher consumption in other resources (cement) and energy (for the pre-treatment) compared with the extraction of virgin resources (natural aggregates). Therefore, case-by-case research of the environmental implications is needed to achieve sustainable solutions. In the particular case of seashell waste, it is necessary to 
research the possibilities of replacing other materials with higher environmental impacts or trying to reduce the environmental footprint of the recycling process.

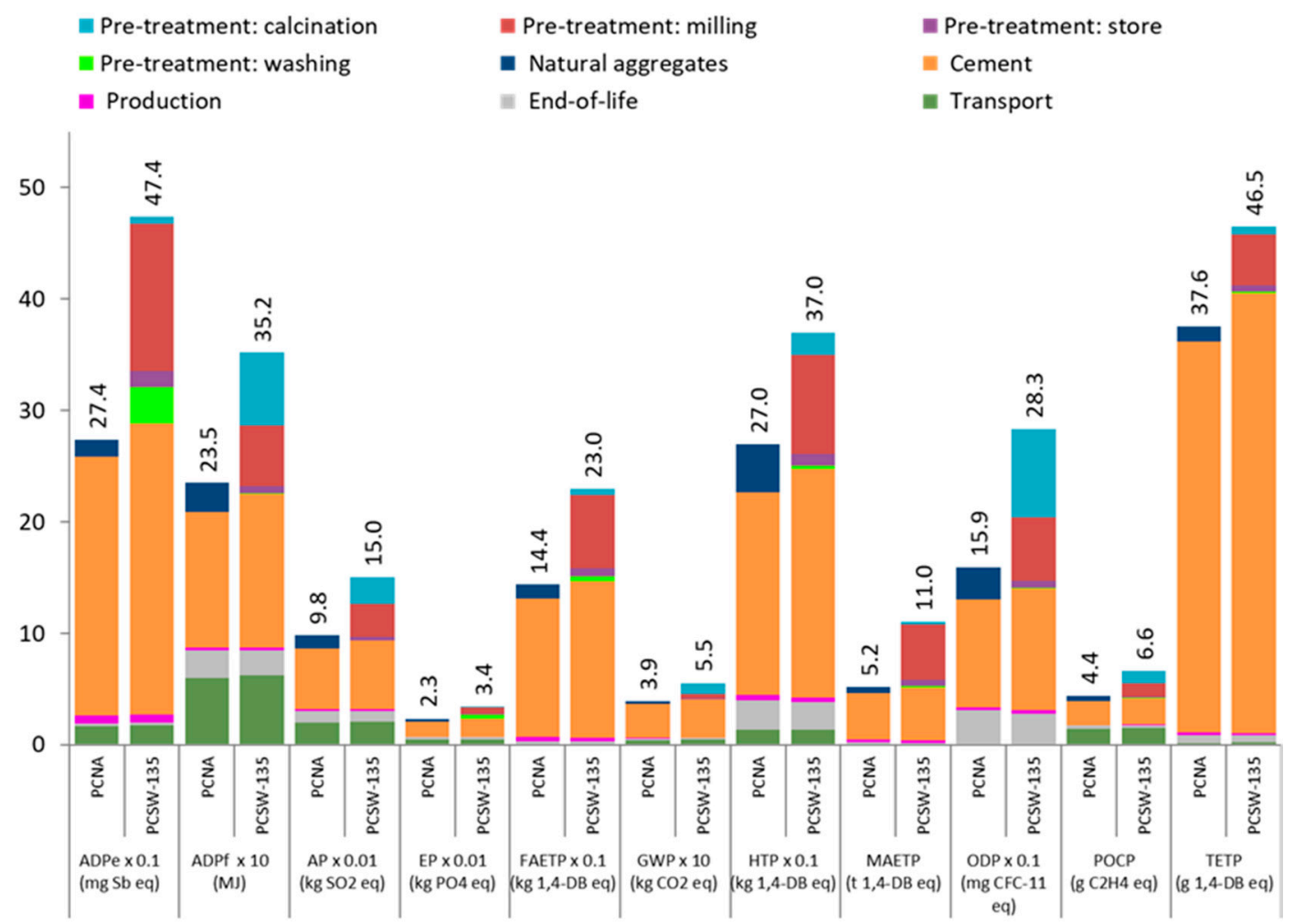

Figure 4. Life cycle environmental impacts of PCNA and PCSW-135 noise barriers. Some impacts should be multiplied by the factor shown to obtain the original values. PCNA: porous concrete with natural aggregates, PCSW-135: porous concrete with seashell waste heated at $135^{\circ} \mathrm{C}$. For the rest of the nomenclatures, consult Figure 2.

\section{Conclusions}

This study provides the first environmental life cycle assessment of seashell waste as an aggregate in porous concrete panels in noise barriers. The results reveal that the noise barriers manufactured with seashell waste have higher impacts (between 32\% and 267\%) than barriers based on porous concrete made with natural aggregates in the 11 categories considered. These increases are justified by the contribution of the seashell waste pre-treatment, including storage, washing, calcination, and milling, and the higher cement consumption, $13 \%$ compared with acoustic barriers with natural aggregates. The impacts caused by the end-of-life and production stages are low in both alternatives $(<19 \%)$, and the transport has a significant influence only in the generation of photochemical oxidants in both types of barriers ( $>15 \%)$.

A decrease in the calcination temperature of seashell waste from $550{ }^{\circ} \mathrm{C}$ to 250 and $135^{\circ} \mathrm{C}$ causes a reduction of $3-36 \%$ and $5-52 \%$ in the different impacts, respectively. However, even the alternative with a lower calcination temperature $\left(135^{\circ} \mathrm{C}\right)$ still has higher impacts in all the considered categories than the noise barrier made with natural aggregates. The decrease in the calcination temperature turns the consumption of cement into the primary contributor in all of the impact categories. In this sense, future research studies should analyze the technical feasibility of reducing cement consumption when natural aggregates are substituted with seashell waste. Thus, it could be concluded that life cycle assessments should be carried out simultaneously with the technical development of the product and not at the end. This approach would simultaneously make it possible to optimize the technical properties of the materials and minimize their environmental impact and, combined with a socio-economic analysis, will ensure the sustainability of the recycling process. 
Supplementary Materials: The following are available online at http://www.mdpi.com/2227-9717/8/7/776/s1, Figure S1: Acoustic noise barrier dimensions, Table S1: Inventory data for the seashell waste pre-treatment per $1 \mathrm{~m}^{2}$ of noise barrier when different calcination temperatures are applied (PCSW, $550{ }^{\circ} \mathrm{C}$; PCSW-250, $250{ }^{\circ} \mathrm{C}$; PCSW-135, $\left.135^{\circ} \mathrm{C}\right)$.

Author Contributions: Conceptualization, B.A.-F., A.G.-S. and C.L.; methodology, B.P., A.G.-S. and B.A.-F.; software, B.P., A.G.-S. and B.A.-F.; validation, B.P., A.G.-S., B.A.-F. and C.L.; formal analysis, B.P., A.G.-S. and B.A.-F.; investigation, B.P., A.G.-S., B.A.-F. and C.L.; resources, A.G.-S., B.A.-F. and C.L.; data curation, B.P., A.G.-S. and B.A.-F.; writing-original draft preparation, B.P., A.G.-S. and B.A.-F.; writing-review and editing, B.P., A.G.-S., B.A.-F. and C.L.; visualization, B.P., A.G.-S. and B.A.-F.; supervision, A.G.-S., C.L. and B.A.-F.; project administration, B.P.; funding acquisition, B.P and C.L. All authors have read and agreed to the published version of the manuscript.

Funding: This research was funded by Innovation Funds for competitiveness from Regional Government of Coquimbo (Chile), grant number BIP 40014353-0.

Acknowledgments: The authors would like to acknowledge Carmen Barros and Diego Iribarren for their contribution to the article.

Conflicts of Interest: The authors declare no conflict of interest.

\section{References}

1. Estanqueiro, B.; Dinis Silvestre, J.; De Brito, J.; Duarte Pinheiro, M. Environmental life cycle assessment of coarse natural and recycled aggregates for concrete. Eur. J. Environ. Civ. Eng. 2016, 22, 429-449. [CrossRef]

2. Ingrao, C.; Arcidiacono, C.; Bezama, A.; Ioppolo, G.; Winans, K.; Koutinas, A.; Gallego-Schmid, A. Sustainability issues of by-product and waste management systems to produce building material commodities. Resour. Conserv. Recycl. 2017, 126, 4-5. [CrossRef]

3. Ingrao, C.; Arcidiacono, C.; Bezama, A.; Ioppolo, G.; Winans, K.; Koutinas, A.; Gallego-Schmid, A. Sustainability issues of by-product and waste management systems, to produce building material commodities: A comprehensive review of findings from a virtual special issue. Resour. Conserv. Recycl. 2019, 146, 358-365. [CrossRef]

4. Alonso-Fariñas, B.; Rodríguez-Galán, M.; Arenas, C.; Arroyo Torralvo, F.; Leiva, C. Sustainable management of spent fluid catalytic cracking catalyst from a circular economy approach. J. Waste Manag. 2020, 110, 10-19. [CrossRef]

5. Rodríguez-Galán, M.; Alonso-Fariñas, B.; Baena-Moreno, F.M.; Leiva, C.; Navarrete, B.; Vilches, L.F. Synthetic slag production method based on a solid waste mix vitrification for the manufacturing of slag-cement. Materials 2019, 12, 208. [CrossRef]

6. Gallego-Schmid, A.; Chen, H.M.; Sharmina, M.; Mendoza, J.M.F. Links between circular economy and climate change mitigation in the built environment. J. Clean. Prod. 2020, 260, 121115. [CrossRef]

7. Srivastava, R.R.; Kim, M.S.; Lee, J.C.; Jha, M.K.; Kim, B.S. Resource recycling of superalloys and hydrometallurgical challenges. J. Mater. Sci. 2014, 49, 4671-4686. [CrossRef]

8. Kim, T.G.; Srivastava, R.R.; Jun, M.; Kim, M.; Lee, J.C. Hydrometallurgical recycling of surface-coated metals from automobile-discarded ABS plastic waste. J. Waste Manag. 2018, 80, 414-422. [CrossRef]

9. Sattar, R.; Ilyas, S.; Bhatti, H.N.; Ghaffar, A. Resource recovery of critically-rare metals by hydrometallurgical recycling of spent lithium ion batteries. Sep. Purif. Technol. 2014, 49, 4671-4686. [CrossRef]

10. Nekouei, R.K.; Maroufi, S.; Assefi, M.; Pahlevani, F.; Sahajwalla, V. Thermal isolation of a clean alloy from waste slag and polymeric residue of electronic waste. Processes 2020, 8, 53. [CrossRef]

11. Zaimes, G.G.; Vora, N.; Chopra, S.S.; Landis, A.E.; Khanna, V. Design of sustainable biofuel processes and supply chains: Challenges and opportunities. Processes 2015, 3, 634-663. [CrossRef]

12. Langer, W. Sustainability of aggregates in construction. In Sustainability of Construction Materials, 2nd ed.; Khatib, J.M., Ed.; Elselvier: London, UK, 2016; pp. 181-207.

13. Sreebha, S.; Padmalal, D. Environmental impact assessment of sand mining from the small catchment rivers in the Southwestern Coast of India: A case study. Environ. Manag. 2011, 47, 130-140. [CrossRef] [PubMed]

14. BOE. Law 7/1992, de 24 de July, about River Fishing, of Comunidad Autónoma de Galicia, BOE 1992, Pages 34618 to 34625. Available online: https://www.boe.es/eli/es-ga/1/1992/07/24/7 (accessed on 21 February 2020).

15. Hill, A.R.; Dawson, A.R.; Mundy, M. Utilisation of aggregate materials in road construction and bulk fill. Resour. Conserv. Recycl. 2001, 32, 305-320. [CrossRef] 
16. Union Européenne des Producteurs de Granulat (UEPG). Stadistic. 2018. Available online: http://www.uepg. eu/statistics/estimates-of-production-data/data-2015 (accessed on 23 July 2018).

17. Arenas, C.; Luna-Galiano, Y.; Leiva, C.; Vilches, L.F.; Arroyo, F.; Villegas, R.; Fernández-Pereira, C. Development of a fly ash-based geopolymeric concrete with construction and demolition wastes as aggregates in acoustic barriers. Constr. Build. Mater. 2017, 134, 433-442. [CrossRef]

18. Xu, G.; Shen, W.; Zhang, B.; Li, Y.; Ji, X.; Ye, Y. Properties of recycled aggregate concrete prepared with scattering-filling coarse aggregate process. Cem. Concr. Compos. 2018, 93, 19-29. [CrossRef]

19. Mo, K.H.; Alengaram, U.J.; Jumaat, M.Z.; Yap, S.P.; Lee, S.C. Green concrete partially comprised of farming waste residues: A review. J. Clean. Prod. 2016, 117, 122-138. [CrossRef]

20. Chandni, T.J.; Anand, K.B. Utilization of recycled waste as filler in foam concrete. J. Build. Eng. 2018, 19, 154-160. [CrossRef]

21. Yan, N.; Chen, X. Sustainability: Don't waste seafood waste. Nature 2015, 524, 155-157. [CrossRef]

22. Lu, J.; Cong, X.; Li, Y.; Hao, Y.; Wang, C. Scalable recycling of oyster shells into high purity calcite powders by the mechanochemical and hydrothermal treatments. J. Clean. Prod. 2018, 172, 1978-1985. [CrossRef]

23. Lu, J.; Lu, Z.; Li, X.; Xu, H.; Li, X. Recycling of shell wastes into nanosized calcium carbonate powders with different phase compositions. J. Clean. Prod. 2015, 92, 223-229. [CrossRef]

24. Yao, Z.; Xia, M.; Li, H.; Chen, T.; Ye, Y.; Zheng, H. Bivalve Shell: Not an abundant useless waste but a functional and versatile biomaterial. Crit. Rev. Environ. Sci. Technol. 2014, 44, 2502-2530. [CrossRef]

25. Ballester, P.; Mármol, I.; Morales, J.; Sánchez, L. Use of limestone obtained from waste of the mussel cannery industry for the production of mortars. Cem. Concr. Res. 2007, 37, 559-564. [CrossRef]

26. Yang, E.I.; Yi, S.T.; Leem, Y.M. Effect of oyster shell substituted for fine aggregate on concrete characteristics: Part I. Fundamental properties. Cem. Concr. Res. 2005, 35, 2175-2182. [CrossRef]

27. Yang, E.I.; Kim, M.Y.; Park, H.G.; Yi, S.T. Effect of partial replacement of sand with dry oyster shell on the long-term performance of concrete. Constr. Build. Mater. 2010, 24, 758-765. [CrossRef]

28. Yoon, H.; Park, S.; Lee, K.; Park, J. Oyster shell as substitute for aggregate in mortar. Waste Manag. Res. 2004, 22, 158-170. [CrossRef] [PubMed]

29. Adewuyi, P.; Adegoke, T. Exploratory study of periwinkle shells as coarse aggregates in concrete works. ARPN J. Eng. Appl. Sci. 2008, 3, 1-5.

30. European Committee for Standardization (EN). Tests for Chemical Properties of Aggregates_Part 1: Chemical Analysis; EN 1744-1; EN: Brussels, Belgium, 2009.

31. Felipe-Sesé, M.; Eliche-Quesada, D.; Corpas-Iglesias, F.A. The use of solid residues derived from different industrial activities to obtain calcium silicates for use as insulating construction materials. Ceram. Int. 2011, 37, 3019-3028. [CrossRef]

32. Foti, D.; Cavallo, D. Mechanical behavior of concretes made with non-conventional organic origin calcareous aggregates. Constr. Build. Mater. 2018, 179, 100-106. [CrossRef]

33. Chen, H.Y.; Li, L.G.; Lai, Z.; Kwan, A.; Chen, P.; Ng, P.L. Effects of crushed oyster shell on strength and durability of marine concrete containing fly ash and blastfurnace slag. J. Mater. Sci. 2019, 25, 97-107.

34. Lertwattanaruk, P.; Makul, N.; Siripattarapravat, C. Utilization of ground waste seashells in cement mortars for masonry and plastering. J. Environ. Manag. 2012, 111, 133-141. [CrossRef]

35. Li, G.; Xu, X.; Chen, E.; Fan, J.; Xiong, G. Properties of cement-based bricks with oyster-shells ash. J. Clean. Prod. 2015, 91, 279-287. [CrossRef]

36. Alvarenga, R.A.F.; De Galindro, B.M.; Helpa, C.F.; Soares, S.R. The recycling of oyster shells: An environmental analysis using Life Cycle Assessment. J. Environ. Manag. 2012, 106, 102-109. [CrossRef] [PubMed]

37. Iribarren, D.; Moreira, M.T.; Feijoo, G. Implementing by-product management into the life cycle assessment of the mussel sector. Resour. Conserv. Recycl. 2010, 54, 1219-1230. [CrossRef]

38. World Health Organization (WHO). Environmental noise guidelines for the European region. Proceedings of the Institute of Acoustics; World Health Organization Regional Office for Europe: Copenhagen, Denmark, 2018; p. 181.

39. European Parliament and Council of the European Union (EC). Directive 2002/49/Ec of the European Parliament and of the Council of 25 June 2002 relating to the assessment and management of environmental noise. Off. J. Eur. Communities 2002, L189, 12-25. Available online: http://eur-lex.europa.eu/legal-content/ EN/TXT/PDF/?uri=CELEX:32002L0049andfrom=EN (accessed on 3 June 2020). 
40. Kotzen, B.; English, C. Book Environmental Noise Barriers—A Guide to Their Acoustic and Visual, 2nd ed.; Taylor \& Francis: New York, NY, USA, 2009; pp. 15-38.

41. Peceño, B.; Arenas, C.; Alonso-Fariñas, B.; Leiva, C. Substitution of coarse aggregates with mollusk-shell waste in acoustic-absorbing concrete. J. Mater. Civ. Eng. 2019, 31, 04019077. [CrossRef]

42. Galician Statistical Institute (IGE). Production of Marine Aquaculture in Galicia. 2017. Available online: https://www.ige.eu/web/mostrar_actividade_estatistica.jsp?idioma=esandcodigo=0301004 (accessed on 12 June 2018).

43. Eurostat. Catches-Major Fishing Areas (from 2000 Onwards). 2019. Available online: https://appsso. eurostat.ec.europa.eu/nui/show.do?dataset=fish_ca_mainandlang=en (accessed on 21 February 2020).

44. International Standards Organization (ISO). Environmental Management_Life Cycle Assessment_Principles and Framework, ISO 14040; ISO: Geneva, Switzerland, 2006.

45. International Standards Organization (ISO). Environmental Management_Life Cycle Assessment-Requirements and Guidelines, ISO 14044; ISO: Geneva, Switzerland, 2006.

46. ACH. Noise Barriers. Available online: http://www.barrieresach.com/pantallas-barreras-acusticas-ACH (accessed on 18 August 2019).

47. Pan Rodo. Noise Barriers. Available online: https://www.obralia.com/dir/minisites/catalogos/419295/ catalogo.pdf (accessed on 18 June 2018).

48. European Committee for Standardization (EN). Road Traffic Noise Reducing Devices-Test Method for Determining the Acoustic Performance -Part 1: Intrinsic Characteristics of Sound Absorption under Diffuse Sound Field Conditions; EN 1793-1; EN: Brussels, Belgium, 2017.

49. Moreno Ruiz, E.; Valsasina, L.; Brunner, F.; Symeonidis, A.; FitzGerald, D.; Treyer, K.; Bourgault, G.; Wernet, G. Documentation of Changes Implemented in Ecoinvent Data 3.1; Ecoinvet: Zurich, Switzerland, 2014; p. 70.

50. European Commission (EC). Commission Decision on the European List of Waste (COM 2000/532/EC). Off. J. Eur. Communities 2000, 50, 1-31.

51. Galvez-Martos, J.L.; Styles, D.; Schoenberger, H.; Zeschamar-Lahl, B. Construction and demolition waste best management practice in Europe. Resour. Conserv. Recycl. 2018, 136, 166-178. [CrossRef]

52. Barros, M.C.; Bello, P.M.; Bao, M.; Torrado, J.J. From waste to commodity: Transforming shells into high purity calcium carbonate. J. Clean. Prod. 2009, 17, 400-407. [CrossRef]

53. Google Maps. Distances. 2020. Available online: https://www.google.com/maps/ (accessed on 2 March 2020).

54. Mercante, I.T.; Bovea, M.D.; Ibáñez-Forés, V.; Arena, A.P. Life cycle assessment of construction and demolition waste management systems: A Spanish case study. Int. J. Life Cycle Assess. 2012, 17, 232-241. [CrossRef]

55. European Parliament and of the Council (EC). Regulation (EC) No 715/2007 of the European Parliament and of the Council of 20 June 2007 on Type Approval of Motor Vehicles with Respect to Emissions from Light Passenger and Commercial Vehicles (Euro 5 and Euro 6) and on Access to Vehicle Repair and Maintenance Information. Available online: https://eur-lex.europa.eu/eli/reg/2007/715/oj (accessed on 16 April 2019).

56. Barros, C.; Bello, P.; Valiño, S.; Bao, M.; Arias, J. Odours prevention and control in the shell waste valorisation. In Proceedings of the International Symposium on EcoTopia Science (ISETS07), Nagoya, Japan, 23-25 November 2007; pp. 890-895.

57. Neves, N.M.; Mano, J.F. Structure/mechanical behavior relationships in crossed-lamellar seashells. Mater. Sci. Eng. C 2015, 25, 113-118. [CrossRef]

58. Sahari, F.; Aniza, N. Cockle shell as an alternative construction material for artificial reef. In Proceedings of the International Conference on Creativity and Innovation for Sustainable Development, Sarawak, Malaysia, 12-14 September 2011.

59. Martínez-García, C.; González-Fonteboa, B.; Martínez-Abella, F.; Carro-López, D. Performance of mussel shell as aggregate in plain concrete. Constr. Build. Mater. 2017, 139, 570-583.

60. PRé Consultants. SimaPro 8.0.4.LCA Software and Database Manual; PRé Consultants, B.V.: Amersfoort, The Netherlands, 2016.

61. Guinee, J.B.; Gorrèe, M.; Heijungs, R.; Huppes, G.; Kleijn, G.R.; van Oers, R.L.; Wegener, L.; Sleeswijk, A.; Suh, S.; Udo de Haes, H.A.; et al. Life Cycle Assessment, an Operational Guide to the ISO Standards. Part 2a; Guide Kluwer Academic Publishers: Dordrecht, The Netherlands, 2001.

62. Silva, R.V.; De Brito, J.; Dhir, R.K. Fresh-state performance of recycled aggregate concrete: A review. Constr. Build. Mater. 2018, 178, 19-31. [CrossRef] 
63. Heyes, G.; Sharmina, M.; Mendoza, J.M.F.; Gallego-Schmid, A.; Azapagic, A. Developing and implementing circular economy business models in service-oriented technology companies. J. Clean. Prod. 2018, 177, 621-632. [CrossRef]

64. Mendoza, J.M.F.; Sharmina, M.; Gallego-Schmid, A.; Heyes, G.; Azapagic, A. Integrating backcasting and eco-design for the circular economy: The BECE framework. J. Ind. Ecol. 2017, 21, 526-544. [CrossRef]

65. Mendoza, J.M.F.; Gallego-Schmid, A.; Azapagic, A. Building a business case for implementation of a circular economy in higher education institutions. J. Clean. Prod. 2019, 220, 553-567. [CrossRef]

66. European Commission (EC). Towards a Circular Economy: A Zero Waste Programme for Europe. 2014. Available online: https://ec.europa.eu/environment/circular-economy/pdf/circular-economy-communication. pdf (accessed on 3 June 2020).

67. Kalmykova, Y.; Sadagopan, M.; Rosado, L. Circular economy-From review of theories and practices to development of implementation tools. Resour. Conserv. Recycl. 2018, 135, 190-201. [CrossRef]

68. Ianni, F.; Segoloni, E.; Blasi, F.; Di Maria, F. Low-molecular-weight phenols recovery by eco-friendly extraction from Quercus spp. wastes: An analytical and biomass-sustainability evaluation. Processes 2020, 8, 387. [CrossRef]

(C) 2020 by the authors. Licensee MDPI, Basel, Switzerland. This article is an open access article distributed under the terms and conditions of the Creative Commons Attribution (CC BY) license (http://creativecommons.org/licenses/by/4.0/). 